\title{
HLA-A Gene
}

National Cancer Institute

\section{Source}

National Cancer Institute. HLA-A Gene. NCI Thesaurus. Code C28585.

This gene is involved in immune responses and histocompatibility processes. 